\title{
EFFECTS OF SOLAR ENERGY USE ON RURAL COMMUNITY: A STUDY OF BOYARJAPHA VILLAGE IN PAIKGACHHA UPAZILA
}

\author{
S. Alam ${ }^{1 *} \&$ R. Ahasan ${ }^{2}$ \\ ${ }^{I}$ Development Design Consultant (DDC), Khulna, Bangladesh \\ ${ }^{2}$ URP Discipline, Khulna University, Khulna, Bangladesh \\ "Corresponding Author: saimonurp07@yahoo.com
}

\begin{abstract}
Renewable energy is of great importance for today's world which is generally produced from natural sources. Countries like Bangladesh has to use this energy to meet their energy demand. Day by day the demand of electricity is increasing in stormy pace but our resource is limited. So using renewable resources i.e. solar power to meet the demand of electricity is highly necessary especially rural and remote areas. This paper examined the nature and extent of solar energy in Boyarjapha village of Paikgachha Upazila of Khulna district to analyse the effects of solar panel in their daily life. Many positive impacts of solar power were found out such as better quality lighting, education, entertainment, communications, business, increasing working hours, women empowerment, increasing awareness etc. There are a few bad effects of solar energy too. But Government intervention is a must to ensure better quality results in coming future. Similarly, government has to take serious steps to advertise solar electricity in remote areas of Bangladesh
\end{abstract}

Keywords: Renewable Energy; solar energy; women empowerment

\section{INTRODUCTION}

The fact that, Bangladesh suffers from an acute crisis of energy, is more due to lack of appropriate resource management rather than the endowment of its energy resources. In terms use of energy from renewable sources, the country could not make any mentionable break-through, excepting in the Solar Photovoltaic Home System (SHS) for off-grid electrification of remote rural areas and to some extent. For several years, Government of Bangladesh has embarked upon a program of Power Sector reforms. These include bringing the entire country under affordable and reliable electricity supply, increasing the energy sector's efficiency, including electricity supply to remote rural areas of the country. Such measures, it has been argued, would bring the country on the road to energy security and sustainability. Important steps in this direction, include wider scale tapping of renewable sources of energy and implementing measures for energy efficiency and energy conservation so that maximum people gets the benefit of energy and electricity. Total energy consumption of Bangladesh is $237.32 \mathrm{PJ}$ in 1995 (Azad, 2006). The total annual per capita energy consumption of the country in 1995 was estimated at $8.467 \mathrm{GJ}$ (Mamun, 2009) The shares of commercial energy (coal, oil, gas and hydropower) and biomass fuels were estimated at 3.203 and 5.264 GJ, respectively (Mamun, 2009). Almost all rural households use open chula (stove) for cooking and these stoves are usually fed by dry leaves, fuel wood, agro-wastes, and rice husk and cow dung. Many affluent rural people use kerosene stoves, gas stoves (fed by LP gas) and electric heaters (where electricity is available) for cooking. Some households use imported coal and a few have locally constructed biogas plants for the purpose. About $4 \%$ of the rural people depend on kerosene for lighting after dusk and a substantial number of farmers use diesel for running pump machines to irrigate lands (Banglapedia, 2008).

Only a few towns/cities of the eastern part of the country have a supply of piped gas. A vast majority of the country's urban and rural households thus depend on fuel woods, the annual consumption of which is about 40 million tons, for cooking (Banglapedia, 2008). This is causing fast depletion of the forest reserve of the country and has become a threat to the ecological balance. It is expected that Renewable Energy Technologies (RET's) can play a significant role in the far-flung remote locations of Bangladesh. As Bangladesh is a tropical country, sunlight is available here all the year round. There are many originations providing solar systems in Bangladesh. 


\section{METHODOLOGY}

For the purpose of this research, Boyarjapha village of Paikgache upazila was selected which is one of the remotest area in the upzila. People use solar energy for their daily purposes. About $50 \%$ people of this village use solar energy. Several NGOs work here with solar energy. So this area is suitable for the research. The total population of the village is 1202. Among them 599 are male and 633 are female. Population growth is $1.8 \%$. In ward no. Birth rate is 2.25 and death rate is 1.25 (BBS, 2008). The total number of household is 246 . It is estimated that about $36 \%$ households have joint family and $64 \%$ households have single family. The average family size is 5.2. The total area of Boyarjapha village is 531 acres. This area covers mainly residential, agricultural and other uses. Both primary and secondary data were collected through intensive field survey and from the involved NGOs and other organizations.

\section{Opportunities of Solar Energy in Bangladesh}

Renewable energy is energy generated from natural resources- such as sunlight, wind, rain, tides and geothermal heat- which are renewable (naturally replenished). In 2006, about $18 \%$ of global final energy consumption came from renewable, with $13 \%$ coming from traditional biomass, such as wood-burning. Hydroelectricity was the next largest renewable source, providing 3\%, followed by solar hot water/heating, which contributed $1.3 \%$. Modern technologies, such as geothermal energy, wind power, solar power, and ocean energy together provided some $0.8 \%$ of final energy consumption (Unique. 2007).

\section{Existing Energy Consumption Pattern}

Conventional fuel consumption per head is 16.5 litre of petroleum per year \% (Biswas et al. ,2007) Cow dung, leaves, Trees, Agri- residue, Kerosene are used for cooking purpose. Kerosene is widely used for lighting at night. Candle light is also used for lighting.

\section{Problems of Existing Energy Practice}

People cut down trees for woods. Woods are widely used for cooking purpose. People destroy forests to collect wood. Decreasing agricultural productivity: Cow dung is good manure. The women also use cow dung for their cooking as fuel. It may decrease agricultural productivity Air pollution: Air is polluting from the burning of fossil fuels. Fossil fuels emanate $\mathrm{CO}_{2} \cdot \mathrm{CO}_{2}$ is the main gas to pollute the air. It is also the responsible for greenhouse effect. Health hazard: Smoke is dangerous for health. It causes different diseases. For example, bronchitis, asthma, heart diseases etc. Fire hazard: The traditional energy is not safe. Fire hazard is a common incidence in rural area due to unsafe energy use. Time wasting: To collect fuels (Cow dung, leaves etc.) children and women waste enough time. The traditional cooking procedure is also lengthy.

\section{Reasons for choosing solar energy in Bangladesh}

Bangladesh is situated between 20.30 - 26.38 degrees' north latitude and 88.04- 92.44 degrees east which is an ideal location for solar energy utilization. Daily average solar radiation varies between 4 to $6.5 \mathrm{kWh}$ per square meter. Maximum amount of radiation is available on the month of March-April and minimum on December-January. There is a good prospect of harnessing solar power in Bangladesh. In a recent study conducted by Renewable Energy Research Centre, it is found that average solar radiation varies between 4 to $6.5 \mathrm{kWhm}-2$ day-1. Maximum amounts of radiation are available in the month of March-April and minimum in December-January. Following map has illustrated prospect of solar radiation in Bangladesh (Reein, 2008).

\section{PRESENT SITUATION OF POWER SUPPLY}

The present situation is not satisfactory. Lot less is being produced in terms of demand. Sometimes the existing power station fails. Then the people suffer a lot. The existing condition of the power stations is very poor. The condition of the stations situated in Ghorasal, Shahjibazar, Sikalbaha and Khulna is the most vulnerable. These stations can fail any time. It is called 'forced outage' in the electricity terminology.

Table 1 shows the load shedding in major urban areas in Bangladesh. Gas and diesel are used extensively to generate power. These are non-renewable resources. So these resources must be 
protected. There are some gas fields in our country. The total recoverable reserves of natural gas in 22 known gas fields are $439 \mathrm{Gm} 3$ of which $110 \mathrm{Gm} 3$ was produced up to June 2000 (Mamun et al., 2009). It may be finished within 2050 (Reein, 2008). Diesel is exported and it is very expensive. The price of the oil is increasing day by day. The country has substantial bituminous coal deposits in the north western region at Barapukuria and also more coal fields bear potential for large scale mining of them are under active consideration of Government for exploration. Though there is a power station in Barapukuria but its maximum production capacity is 170MW (Reein, 2008).

Table 1: Power demand in major urban areas

\begin{tabular}{lll}
\hline Major Urban areas & Maximum demand(MW) & Load Shedding(MW) \\
\hline Dhaka (DESA) & 3000 & 177 \\
\hline Chittagong & 860 & 85 \\
\hline Khulna & 890 & 99 \\
\hline Rajshahi & 825 & 107 \\
\hline Comilla & 675 & 62 \\
\hline Mymensingh & 442 & 44 \\
\hline Sylhet & 300 & 51 \\
\hline Barisal & 175 & 20 \\
\hline Rangpur & 400 & 56 \\
\hline Total & 7567 & 701
\end{tabular}

Source: $B P D B, 2016$

Rural Electrification Board (REB) responsible for electrifying rural Bangladesh. Today there are 70 operating rural electric cooperatives called Palli Bidyuit Samity (PBS) (REB, 2008). But the condition of the Palli Bidyuit Samity is worse than the Bangladesh Power Development Board (BPDB). The situation of the rural area is worse than the urban area.

\section{Conceptual Framework of the Study}

Figure 1 shows that there is some initial investment for solar system. With the help of solar energy, the socio-economic development will be achieved. The socio-economic development ensures rural development. Then the income of the people will be increased. When the income increased then the people is able to buy new solar system. It is a development cycle and solar energy is the driver of this cycle.

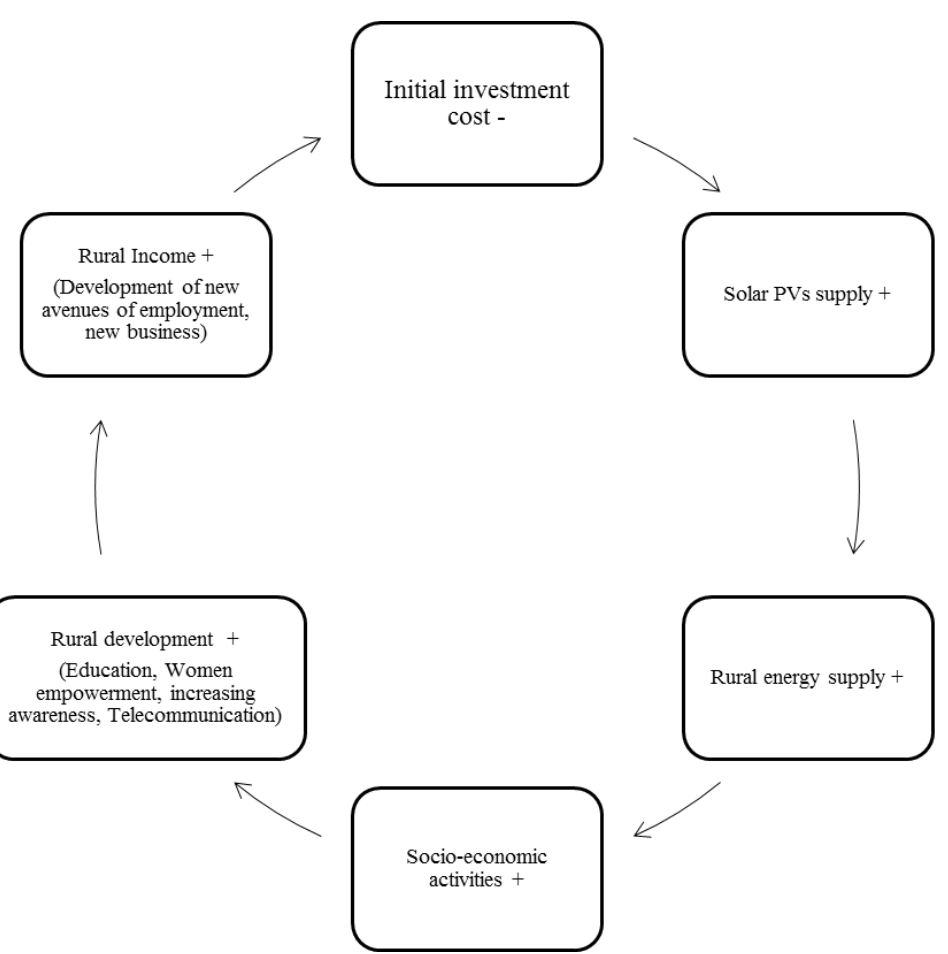

Fig. 1: Conceptual Framework 


\section{RESULTS AND DISCUSSIONS}

Nature and extent of solar energy use, effects of solar energy on rural livelihoods and the factors influencing the use of solar energy in the study area was analyzed throughout the research analysis.

\section{Occupational Distribution of the Household Head}

People of different occupations live in the village. The number of farmers is decreasing and the number of businessmen is increasing. The businessmen group is the richest group. The businessmen are mainly related with shrimp farming (99\%). Teachers, some fishermen (55\%) and some farmers (40\%) earn more than BDT 5000.

\section{Income Distribution of the Villagers}

There are seven types of occupations found in the village. Most of the businessmen and teachers are in good position. Some farmers and fishermen earn a good amount of money. Mainly the businessmen start the use of solar energy in the village. The day labors, van pullers and the small shopkeepers are poor. So they are unable to buy the solar system. The people who earn more than BDT 5000 are able to buy the solar system. Figure 9 shows that

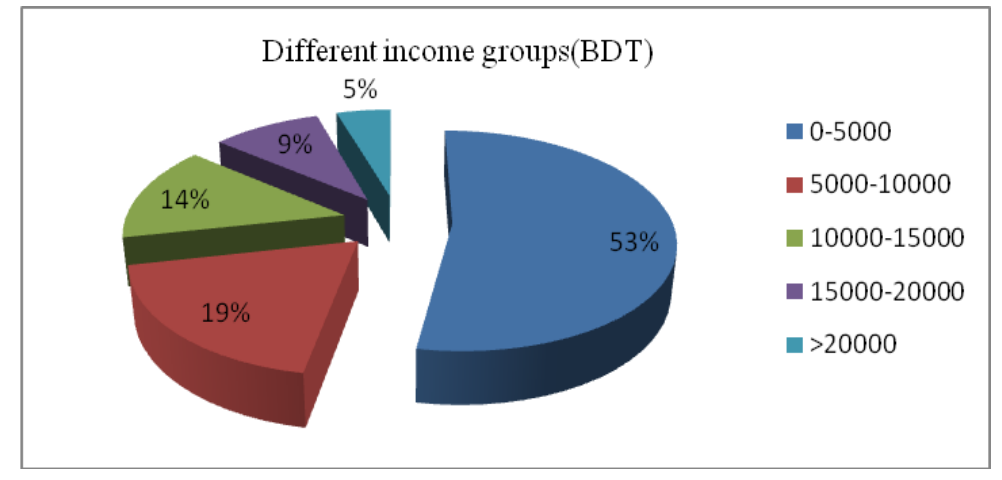

Fig. 3: Income distribution of the villagers about 53\% people of this village earn less than BDT 5000. Rickshaw pullers, van pullers, shopkeepers, some farmers $(60 \%)$ and some fishermen earn less than BDT 5000. So they are deprived to get the facilities of solar energy.

\section{USE OF THE SOLAR ENERGY}

Solar system is very popular in this village. about $46 \%$ people of the village use solar system. 113 Households use solar energy. The use mainly depends on the income. The people don't have solar system very keen to buy a solar system. Hundred percent non solar users want to buy solar system. They always try to manage money for the solar system.

\section{Price of the Solar System}

Ninety-three percent of the total respondents said that the price of the solar system is very high. The rest $7 \%$ people came from the businessman group. Their income is more than BDT 200000 per month. It is very difficult for the rural people to afford solar system. The total price fluctuates between BDT 22500 to BDT 65000. The power of these solar systems varies between 30 watts to 120 watts. The rich people and rich large families usually use high price solar system. The price varies from NGO to NGO.

\section{Percentage of Solar Energy User}

use solar energy a Do not solar energy

Fig. 4: Percentage of solar energy users 
Table 2 shows the price of different solar system according to the capacity. It also shows the number of user of according to the capacity. There is no user of 10 watts to 20 watts. Most of the people use 30 watts to 50 watts powered solar system. The number of user is inversely related with high power and high price.

Table 2: Price of the solar system according to the capacity

\begin{tabular}{c|c|c}
\hline Capacity of the system (watt) & Price (BDT) & User \\
\hline 30 & $18000-18500$ & 22 \\
\hline 40 & $22500-23000$ & 23 \\
\hline 50 & $27000-27500$ & 8 \\
\hline 60 & $31500-32000$ & 5 \\
\hline 65 & $33500-34000$ & 7 \\
\hline 70 & $36500-37000$ & 3 \\
\hline 75 & $38500-39000$ & 5 \\
\hline 85 & $40000-40500$ & 1 \\
\hline 120 & $42500-43000$ & 2 \\
\hline 130 & $62500-63000$ & \\
\hline
\end{tabular}

Source: Author, 2015

There are mainly two types of down payment services. These are $15 \%$ of the total price and $25 \%$ of the total price. Down payment of the solar system fluctuates between BDT 3500 to BDT 9000. The provision of down payment is very difficult for low income people. The monthly installment of solar system fluctuates between BDT 470 to BDT 900 . So it is also very difficult to provide money for monthly installment.

\section{Institutional Support}

There are five NGOs provide solar system in the village. Grameen Sakti is the pioneer to provide solar energy in the village. Other NGOs providing solar energy are BRAC Foundation, Srizony Bangladesh, Thengamara Mahila Shabuj Shangha (TMSS) and Palli Daridra Bimochan Foundation. The NGOs give Warranty for solar panel 20 years, battery for 5 years and charge controller for 3 years five years' warranty for the solar system. The NGO workers provide free monthly checkups during payments of installment. The NGOs also train the people so that they can take care of their systems.

Table 3: Number of clients according to the NGO

\begin{tabular}{cc}
\hline NGO & User \\
\hline Grameen Sakti & 38 \\
\hline BRAC Foundation & 24 \\
\hline Srizony Bangladesh & 23 \\
\hline TMSS & 17 \\
\hline Palli Daridra Bimochan Foundation & 11 \\
\hline
\end{tabular}

Source: Author, 2015

\section{IMPACTS OF SOLAR SYSTEM}

There are a number of positive sides of solar system according to the local people. Those positive impacts are discussed below-

\section{Better quality and uninterrupted lighting}

Better quality lighting occupied the first rank. Most people give it the first priority. The people say better quality lighting make easy their daily work after evening. The people of all ages facilitate by the lighting from solar system. Women are enjoying hazardless and hassle free lighting systems in their daily life. On the other hand, the users are freer from the threat of health and fire hazards.

\section{Educational development}

Most of the rural off-grid schools don't have electricity. Solar energy can be used by these rural schools for different amenities. Modern benefits will not only attract more students, but will also retain quality teachers and staffs currently unwilling to be posted in the off grid areas. In the evening, the school 
facilities can be utilized for other social services like adult education, health education or recreational activities.

\section{Provide more opportunities for entertainment}

Entertainment is part of the life. Before using solar energy, the people were depending mainly on the cinema halls which are situated in the Paikgachha Upazila. The women mainly deprived because it is not easy to go to the Paikgachha sadar. Which is about $10 \mathrm{~km}$ away from the village. Though there are a few number televisions found in the village but those are not accessible for all. Moreover, it was very difficult task to see the television by charging battery. It was really very costly. But now television is available here. There are $101 \mathrm{TV}$ s and 48 VCDs found in the village.

\section{Development of New Avenues of Employment}

Electrification of micro enterprises in the off-grid areas can increase income or create new job opportunities for the rural poor which has been observed from the experience of Grameen Shakti which is a leading NGO involved in the RET sector. There are some other NGOs related with solar energy. Many people work in those NGOs. There are 5 new shops were built after coming the solar energy in the village. The economy of this village is stronger than the previous time. The people use torch to guard the gher. Previously they use the torch run by battery. Now torch is charged by solar energy. So there is no cost of buying battery.

\section{Increased Working Hours}

Solar energy helps to extend the business hours. Most of the rural markets are closed after the sunset and people do not do business after dusk. But with the help of the bright light of SHS, many shopkeepers are doing business till late night and thus their income is increasing. The working hour of women also increase. They also have enough time to take care of the family.

\section{Women Empowerment}

The women are getting the opportunities to earn extra income by utilizing their time after evening by sewing. Some of the women of the village sewing after night and earn money. There are three poultry farm in the village. They are sewing at the evening under the bright light. About 31 women earn money by sewing. There is a sewing club named "Jagrato Mohila Samity" in the village. There are 28 members of this club. The average income of the member of the club is about BDT 700. They also are saving money by sewing own and the family member's cloths.

\section{Increasing Social Awareness}

Though the awareness occupied the last position but it is very important. The awareness is increasing through television. For example, the people said about the Sidr. The people knew the warning of the catastrophic cyclone. Many people went to the cyclone center and take necessary steps to save their property. The people of the village mainly watch BTV. BTV gives enough information about health care. Awareness is also increasing towards the pregnant women and the female child. Women education is increasing due to awareness.

\section{RECOMMENDATIONS}

Despite some negative impacts, solar energy has brought many positive changes in the lives of the people of study area. in order to have a far better result following recommendations have been made-

- The price of the solar system has to be reduced

- New technologies have to be invented- present technology used in the area produce little amount of energy with high cost- Both govt. and NGOs have to invest money to innovate new technology

- Need necessary government involvement. Especially government has to do something for the poor

- Women involvement in solar energy use must be increased-Without the vigorous participation of the women rural empowerment through solar energy may not completely succeed.

- Have to use solar energy in school to educate the students about modern technology.

- Solar energy can be used to electrify the cyclone center in the study area.

- Solar energy should be used for cooking purpose. 
- Use of germanium in amorphous silicon-germanium thin film solar cells- provides residual power generating capacity at night due to background infrared radiation

\section{CONCLUSIONS}

The main conclusions of the research may be presented in a short form. Energy is very important for attaining the goal of development of a country. The solar energy has huge prospects in Bangladesh. This paper has mainly focused to find out the nature of solar energy use and its impacts on rural life in southwest Bangladesh. There are many villages in Bangladesh with no electricity. Solar energy can improve the condition of those villages putting less pressure on government on energy sector.

\section{REFERENCES}

Azad, AK; Nashreen, SW and Sultana, J. 2006. State of Energy Consumption and $\mathrm{CO}_{2}$ Emission in Bangladesh, Royal Swedish Academy of Sciences.

Bangladesh Power Development Board.2016. Summary of Daily Generation Bangladesh Power Development Board. Dhaka, Government of The People's Republic of Bangladesh.

Biswas, WK and Bryce, P. 2007. Model for Empowering Rural Poor through Renewable Energy Technologies in Bangladesh. Environmental Science \& Policy, 4: 333-344.

Chung, KT; Stevens, SE and Bultron, G. 1993. Degradation of azo dyes by environmental microorganism and helminthes. Environ. Toxicol. Chem., 12(2): 121-132.

Mamun, MRA and Alam, MM. 2008. Utilization Pattern of Biomass for Rural Energy Supply in Bangladesh.

Renewable Energy and Environmental Information Network. 2008. Renewable Energy Development \& Energy Efficiency Measure of Bangladesh Power Development Board (BPDB), accessed on March 20, 2015, from http://www.reein.org/solar/index.htm

rrecd. 2008. Solar Resource Information, accessed on March 11, 2015, from http://rredc.nrel.gov/solar/ Rural Electrification Board (2008) accessed on March 13, 2008 from http://www.reb.gov.bd.com 